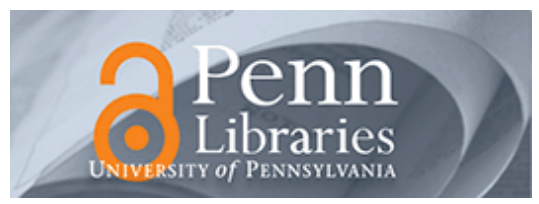

Studies in Visual Communication

Volume 8

Issue 4 Fall 1982

Article 5

1982

Some Observations about Contemporary Cuban Photography: The Union of Cuban Writers and Artists (UNEAC)

Amy Conger

Recommended Citation

Conger, A. (1982). Some Observations about Contemporary Cuban Photography: The Union of Cuban Writers and Artists (UNEAC). 8 (4), 62-80. Retrieved from https://repository.upenn.edu/svc/vol8/iss4/5

This paper is posted at ScholarlyCommons. https://repository.upenn.edu/svc/vol8/iss4/5

For more information, please contact repository@pobox.upenn.edu. 
Some Observations about Contemporary Cuban Photography: The Union of Cuban Writers and Artists (UNEAC) 


\section{Some Observations about Contemporary Cuban Photography: The Union of Cuban Writers and Artists (UNEAC)}

\section{Amy Conger}

Last spring in Mexico City, I saw two exhibitions of Latin American photography, a total of about 670 pictures. Sixty of these were by Cuban photographers. Despite the cultural heritage shared by all these countries, the Cuban images stood out and held together for several reasons-not only because of the high-contrast printing, or the ubiquitous use of the wide-angle lens, or the constant emphasis on unnamed people here-and-now - but, more than anything else, because of their common mood. The photographs were optimistic, energetic, and somewhat playful, not rigid or resigned as one might expect. Themes that were common in other Latin American pictures, such as death, adversity, ethnography, denunciation, and self-consciousness, were not apparent in the Cuban work.

\section{The Photography Subsection}

While any attempt to understand Cuban photography, its makers, and the cultural situation it reflects involves many variables, some generalizations may prove useful, particularly because virtually nothing is known in the United States about Cuban photography. Methodological and political problems will not be solved in this article, but acknowledging their existence does provide perspective. For example, in the last three years I have seen more than 400 photographs made by fifteen Cuban artists during the last decade. I have listened to several lectures on the subject by Cubans and attended a fifteen-hour course on the history of Cuban photography, taught by the Cuban photographer Marío García Joya. I have tried to read what is available on the subject in Spanish and English, and in Mexico City, in May 1981, I interviewed three Cuban photographers:

Amy Conger recently received a Ph.D. in the History of Art, with a specialization in the History of Photography and Graphics, from the University of New Mexico. Twentieth-century North American and Latin American photography are her main interest. Her dissertation, written under the supervision of Beaumont Newhall, on photography by Edward Weston from 1903 to 1926 is being prepared for publication along with two other manuscripts: an anthology of criticism on Weston (with Dr. Newhall) and a catalog for an exhibition of Weston's work in Mexico from 1923 to 1926.

Copyright (c) Amy Conger, 1982.

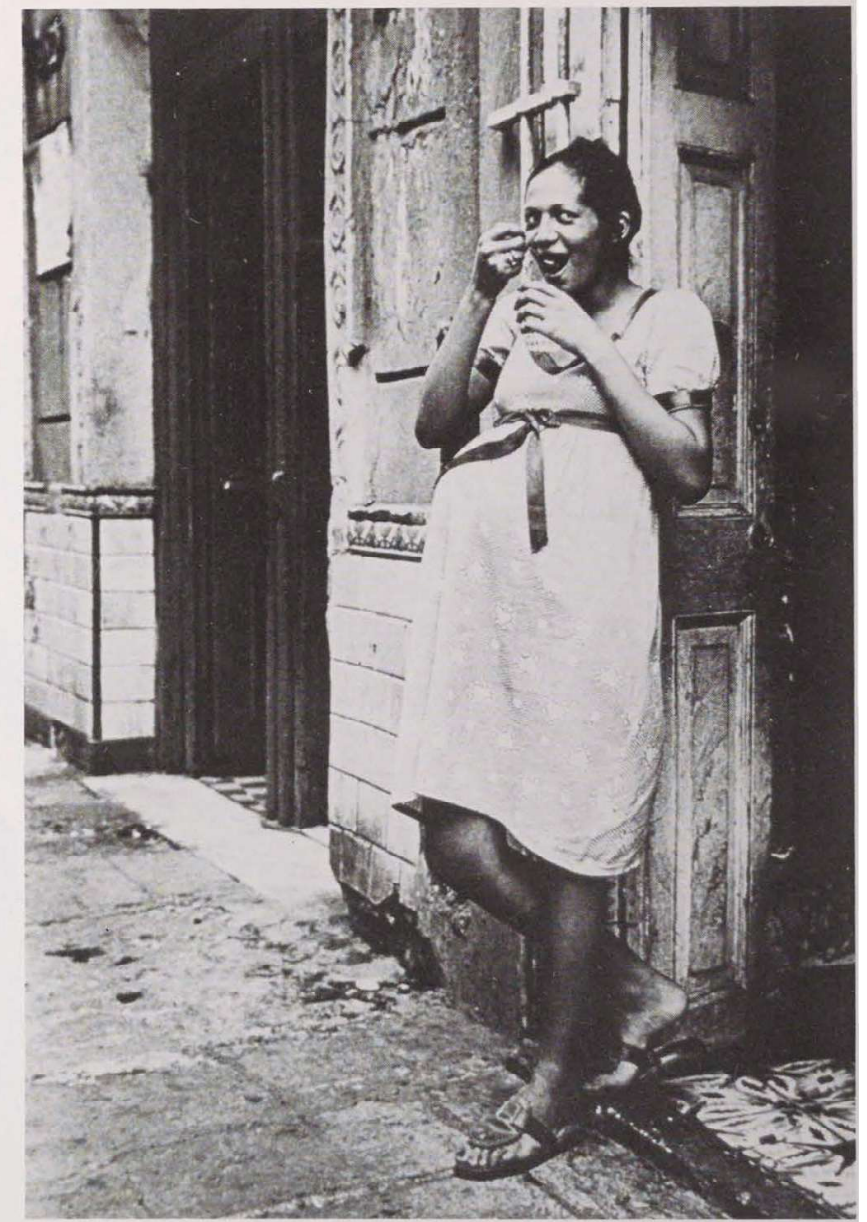

Figure 1 Tito Alvarez. Untitled. From the series "La gente de mi barrio," ca. 1980.

Marío García Joya (Mayito), Raúl Corral Varela (Corrales), and María Eugenia Haya (Marucha). However, all the people I have spoken with and all the works I have seen come from the Photography Subsection of the Unión de Escritores y Artistas de Cuba - the Union of Cuban Writers and Artists (UNEAC) - which is the national council of photography and the organ responsible for selecting works to represent Cuba abroad. In several cases, the collections of Cuban prints were submitted to a jury of Latin American and United States photographers. In one instance, I was able to examine the works that were not accepted and agreed that the jury had chosen the most interesting photographs.

Mayito, who is the director of the Subsection as well as a photographer and filmmaker, described UNEAC as a nongovernmental organization subsi- 


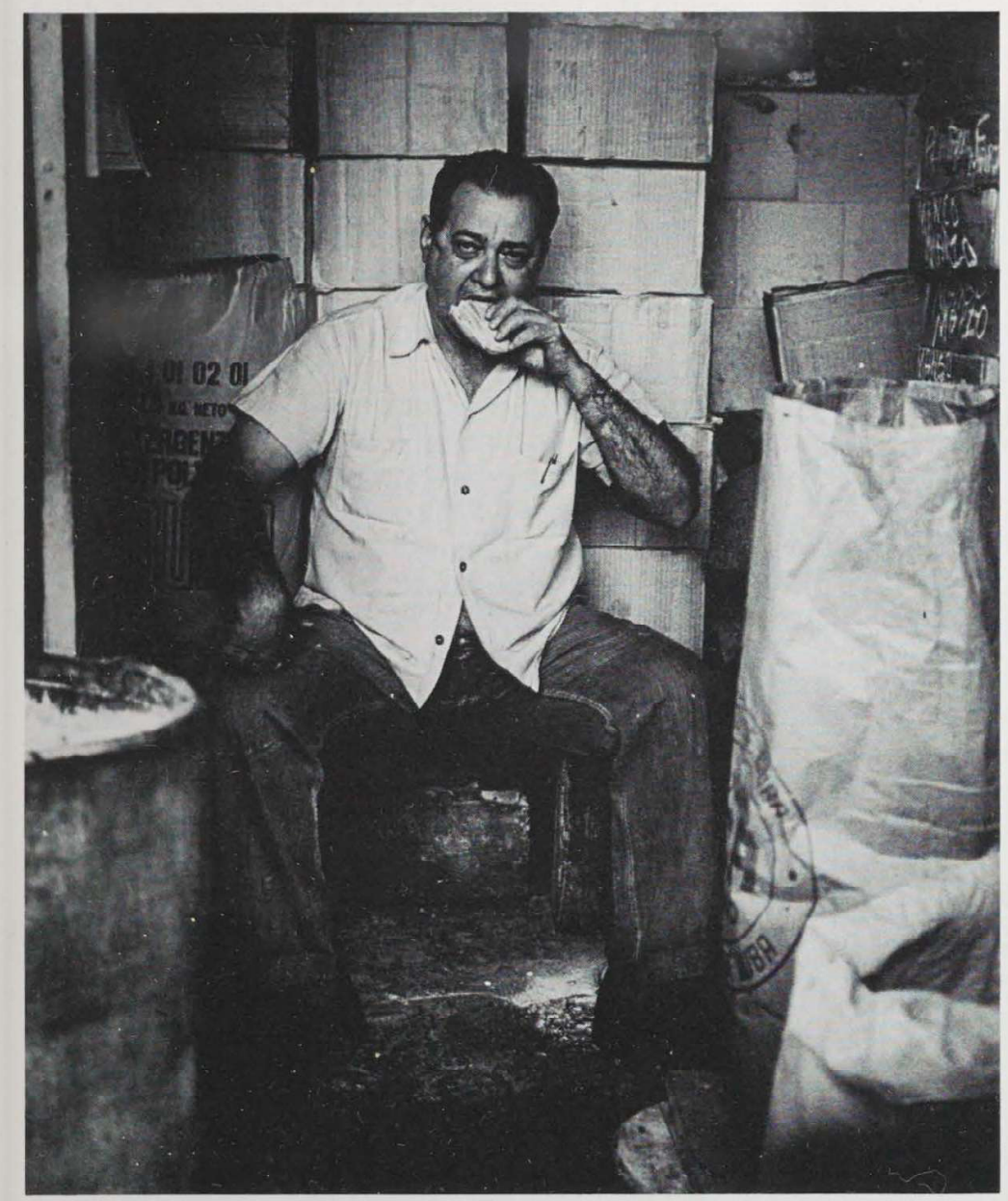

Figure 2 Tito Alvarez. Untitled. From the series "La gente de mi barrio," ca. 1980.

dized by the state. He explained this apparent contradiction by saying that its principles agree with those of the Revolution; although the government supports UNEAC financially, it does not censor the creative work of its members, whom Mayito called "the outstanding artists of the country." Félix Beltrán, a graphic designer and president of UNEAC's Visual Arts Section, stated: "What we don't have is freedom to behave against the system. ... we do not have any stylistic restrictions; we have a topic restriction. ... . we must try to build a better environment for society."2 Mayito said that UNEAC membership was both voluntary and selective: those who wish to become members submit a résumé, a portfolio, and letters of recommendation to the executive committee, which chooses new members on the merits of their work.
The Photography Subsection has a wide variety of functions. Since photography is taught in the journalism departments of the universities, teaching photographic technology is not one of the Subsection's responsibilities. It does sponsor seminars in appreciation and photographic history, subjects not now offered as courses in the universities (although plans are being made to include them in the Cuban studies departments). Another function of the Subsection is to obtain and distribute equipment and materials to its members. Single-lens reflex cameras are not available in retail stores in Cuba, and, consequently, news photographers regularly borrow equipment from their papers; the Subsection, however, can obtain some Soviet cameras for its members and provides darkrooms for them to share. The Subsection also orga- 
nizes international and national exhibitions and sponsors and teaches workshops for children and amateurs. Members have regular weekly meetings where they criticize one another's work and that of other photographers seeking constructive criticism.

I asked Mayito, Marucha, and Corrales specifically about the career of the photographer José Gonzalez Alvarez (Tito Alvarez) because I had noted that although he was born in 1916, I did not recall having seen work by him before the late seventies. Marucha pointed out that I had in fact seen his work - that there was a pictorial-abstract dance picture by him in her essay on the history of Cuban photography (Haya 1979:68). Obviously, it had not impressed me. Tito Alvarez had brought his work to one of the Subsection's Wednesday photo-critiques, where he was told that technically his pictures were very fine but that they lacked "expressiveness." Apparently, he considered this criticism thoughtfully and within a short while began working on the series "La gente de mi barrio" [The people of my neighborhood], in which he managed to use forms, body language, and rhythm more effectively than in his earlier dance pictures (Figures 1, 2, 15, 16).

During the interview, I asked Mayito, Marucha, and Corrales how many of the UNEAC photographers were members of the Communist party. They laughed and Mayito replied, "Not one, I believe." He added, however, that some fine artists, such as the designer Alfredo Rostgaard and the filmmaker Santiago Alvarez, were members of the party.

\section{Issues of Artistic Freedom}

In analyzing the information that is available, it is imperative to discriminate between the ideal and the actual, the verbal and the visual, and the artists' expectations and their accomplishments. This contradiction, in fact, appears in this article, which deals only tangentially with the Cuban society of which art is allegedly an inseparable part. Therefore, either my analysis is lacking or art is not as integrated into society as pages of official statements would lead us to believe. But as Beltrán stated, "We are dialectical, we can change our minds."

Patently, the creative situation in Cuba is not as directed, unilateral, or mechanically homogeneous as it would be facile to believe. For example, I asked three Cubans, all involved with filmmaking, their opinions about a recent Cuban movie, Cantata de Chile [Ballad of Chile]. I was curious about their reactions to this particular film because I considered it artistically and technically quite beautiful but thematically incoherent. Each of them stated clearly in his own way that the film was unfortunately a failure. On the other hand, a leftist art critic from the United States thought about the film at length and presented an abstruse explanation to justify it. Apparently, she was uncomfortable or incapable of accepting the fact that Cubans could botch a film. Beltrán stated the Cuban viewpoint clearly: "We are critical, not of the revolution but of the mistakes.'

With predictable regularity in any discussion on Cuban culture, Fidel Castro's 1961 speech "Words to the Intellectuals" is quoted: "What are the rights of Revolutionary writers and artists? Within the Revolution: all; against the Revolution, none." 3 This worked its way into the 1976 Constitution as follows: "Artistic creation is free as long as its content is not contrary to the Revolution. Forms of artistic expression are free." 4 Sometimes, however, there is a tendency toward rhetorical hyperbole that verges on the incredible. At the 1977 UNEAC Congress, Armando Hart, the Minister of Culture, claimed that the Cubans were in the avant-garde of individual and intellectual freedom since, unlike the capitalists, they represented the interests of the greatest percentage of the population against oppression by a minority. He then proceeded to warn UNEAC members against individualism, elitism, voyeurism, alienation, and thematic speculation (Hart 1977:44-47).

Unofficial statements may be more revealing of the actual situation. Hugh Thomas reported that in 1965 Castro said, "Art is not an end in itself. Man is the end. Making man happier, better. ..." (Thomas 1977: 689). Five years later, the poet-priest Ernesto Cardenal (now Nicaraguan Minister of Culture) described an incident which the painter René Portocarrero had related to him. A Russian or a 


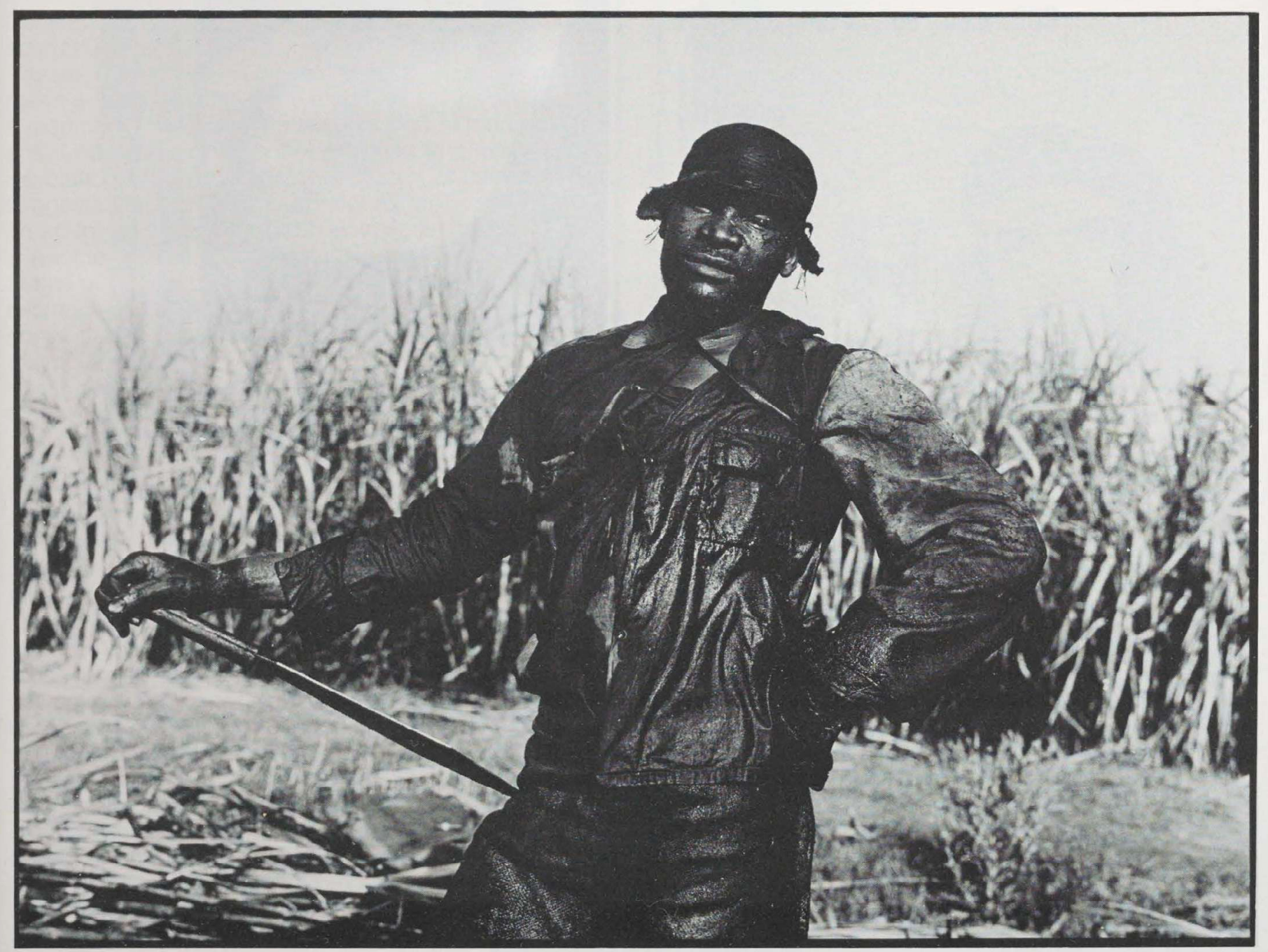

Figure 3 Rigoberto

Romero. Untitled. From

the series "Con sudor de millionario," 1980. 

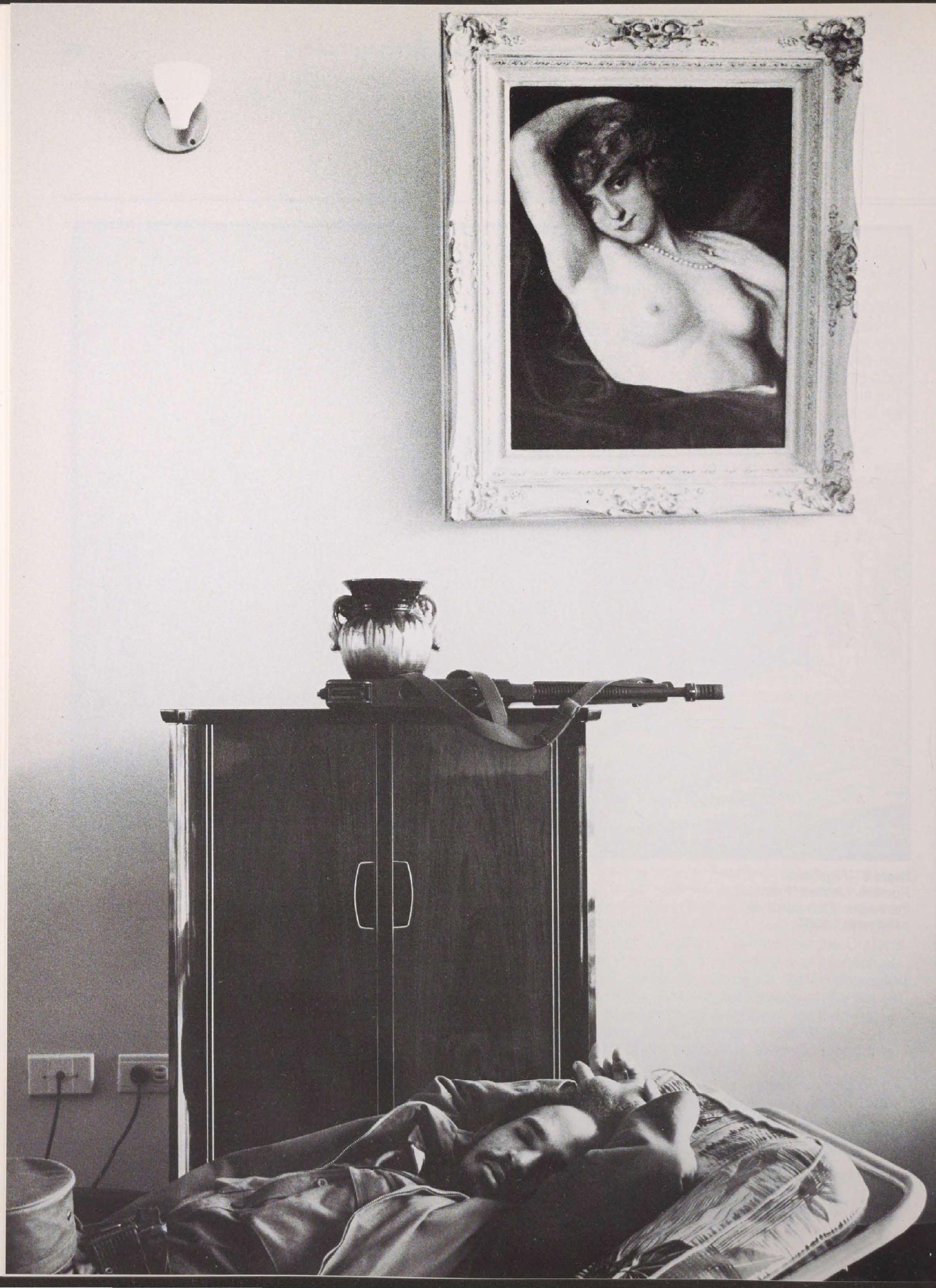
Communist delegate had asked Castro what a semiabstract mural by Portocarrero in the National Palace "meant," and Castro replied: "Nothing. This doesn't mean a thing. It's just some madness . . . painted by a madman for people who like this kind of madness, and it was sponsored by the madmen who made this Revolution." (Cardenal 1974:127). This, of course, suggests that the Cubans are not as removed from an art-for-art's sake aesthetic as is commonly thought.

Another part of misunderstanding in the United States of Cuban photography is caused by simple misreadings owing to varied cultural, social, and economic backgrounds as well as different intentions. For example, the title of Rigoberto Romero's series on sugar cane cutters is "Con sudor de millionario" [With the sweat of a millionaire] (Figure 3). This is not a sarcastic slight on a wealthy capitalist but instead an homage to a worker who has cut about a million pounds of sugar cane in one season and thus made an exceptional contribution to the Cuban economy.

Because of the almost total lack of information and the very infrequent opportunities to see Cuban art in the United States - a situation which is worsening because of the tightening of the embargo on Cuban goods, including movies, magazines, and booksthose tourists who visit Cuba even briefly are endowed with an "expertise" that in other cases would be absurd. Sometimes foreign visitors seem unwilling to accept the fact that every Cuban does not live, breathe, eat, and dream socialism. For example, in Radical America, Steve Cagan, a United States photographer and photo-critic, described Corrales's Dream of a Soldier (Figure 4) as "a sleeping guerrilla; his fatigues and machine-gun contrasting with the opulent, yet decadent interior of an occupied mansion" (Cagan 1980:56). Talking with Corrales, I mentioned that this particular photograph had always amused me. He was pleased; that was the purpose of the picture. Apparently, it had never occurred to him that a viewer could interpret this work as a critical comparison of the rough-and-ready with the opulent and decadent or could imagine that this soldier might be dreaming of the glory of defending the patria. It is common that foreigners interested in the Cuban process feel that a sense of humor is out of place within a socialist framework.

\section{Photographic Styles since 1959}

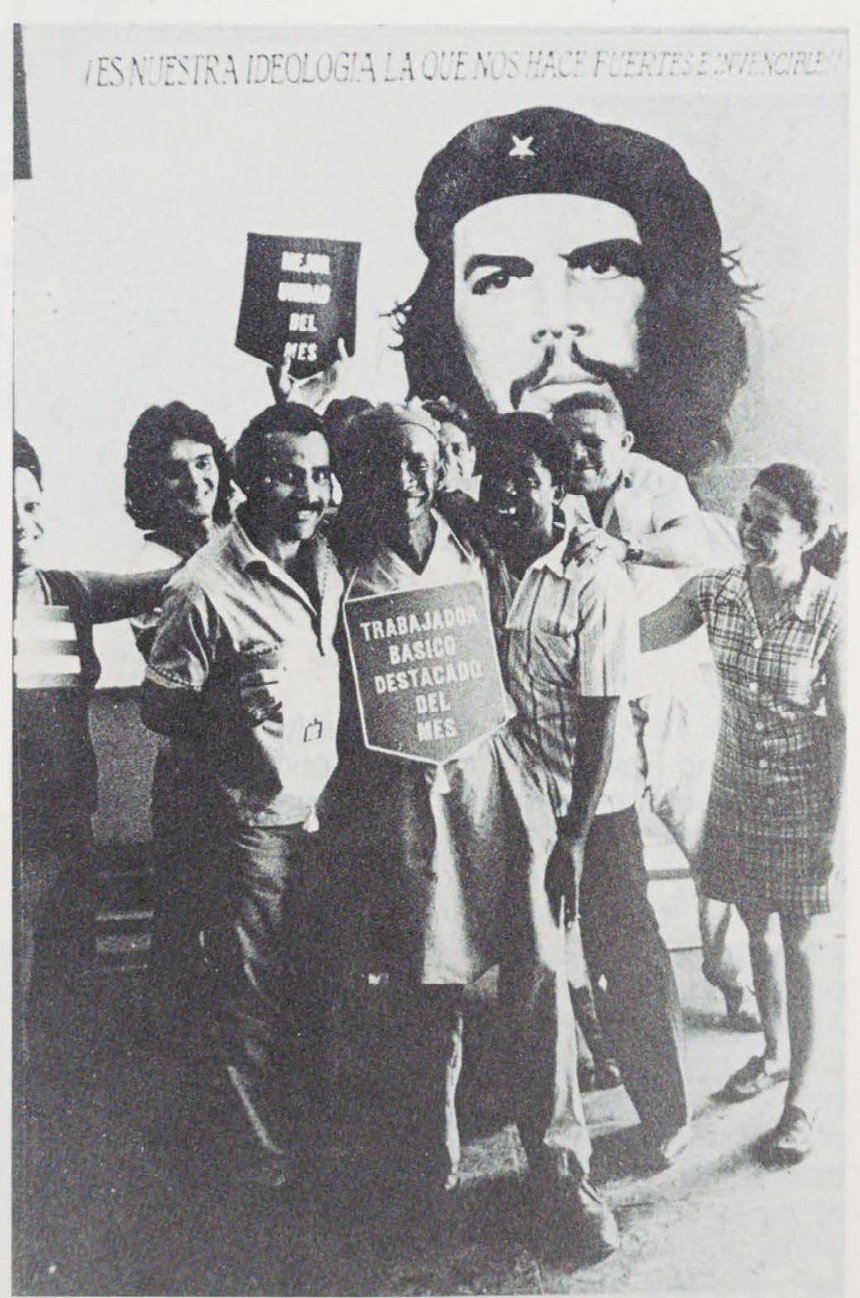

Figure 5 Mayito. Untitled, ca. 1976. (Reproduced from XX Aniversario, p. 88.)

Typical of its retardataire and colonized structure before the Revolution, Cuban photography attempted to follow a course similar to that of industrialized countries. However, after the Revolution in 1959, photographic images tended to be posterlike, frequently posed, almost iconic, and somewhat static. Marucha described this period:

To support the patriotic and dramatic appeals of the Revolution, it was very common that during the most delicate and decisive moments, photography was used as a language to sensitize and mobilize the masses in the press, or was printed right on posters or billboards with texts like the following: "These Cubans Need Your Help,"

"To Arms!" "To the Plaza!" "Commander-in-Chief, At Your Order!" and others. ${ }^{5}$ 
Figure 6 Grandal. Untitled. From the series "La imagen constante," n.d. (Reproduced from Hecho en Latinoamerica, n.p.)

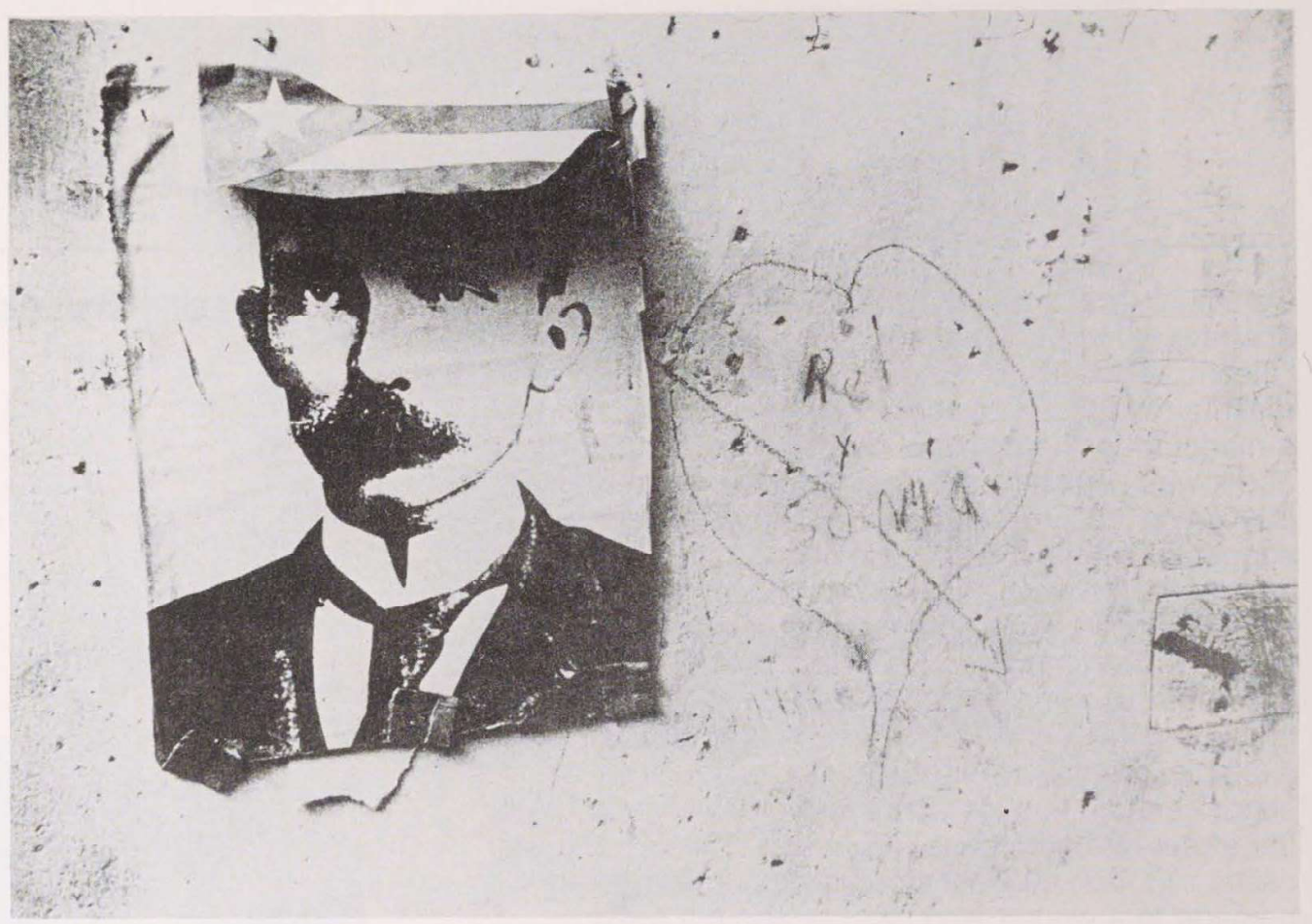

This style survives today, particularly in the work of Mayito and Ramón Grandal. In a photograph by Mayito from the seventies, an old man in the foreground wears a sign that says: "Outstanding Basic Worker of the Month." A mural on the back wall proclaims: "It Is Our Ideology That Makes Us Strong and Invincible!" (Figure 5). The subject of this mural is the photographic portrait of Che Guevara taken by Alberto Korda in 1960, probably the best known of all Cuban photographs. Significantly, however, it has been reproduced in a manicured version: the outlines of the beard, mustache, and eyebrows are sharper than in the original, and the shadow on the right side of the chin has been toned down considerably. On a whole, the face seems more symmetrical, more perfect, and less human.

A portfolio of pictures and a statement by Ramón Grandal were recently published in a Swiss photographic magazine. Part of Grandal's explanation of his photographs reads:

The mere idea of seeing their heroes displayed on the wall gives the Cubans new courage to perform heroic deeds each day. By these means, they determine their position with regard to their political, patriotic and social situation. ... Every Cuban who follows the path set by his hero becomes a living example for others. Cubans sacrifice themselves in a struggle against an enemy who is determined to sow the seeds of his terrible hatred over the continental borders of Africa, Asia and Latin America. Motivation and ideas are free from all creative intention; they represent a compromise between an idea and that which exists forever and proves that Cuba in spite of all her sufferings and struggles, will continue to exist. [Porter 1980:4; translation not mine]
Most likely, Grandal was sincere in his statement, but this type of aggressive rhetoric, seemingly written with a hammer and chisel, is not obvious in his photographs, which are imposing but also somewhat playful (Figures 6, 7). The written text is not consistent with his imagery, suggesting that this style of statement may have been more common in the past than it is today.

A "Iyric" style of photography, as Mayito called it, is more prevalent now and has been popular since the consolidation of the Revolution, a period roughly characterized by the almost complete elimination of illiteracy, an increase in the average level of education, the approval of the National Constitution in 1976, and a slackening of certain basic problems of survival. Mayito said:

As the society itself improved, and the individual was gradually being freed from anxieties dealing with housing, health, and education, general tensions were lessened and an individual could dedicate himself to the product of this reality, and think more about, for example, his girlfriend. ... In music, the love songs of the Nueva Trova would be another example of this. ... [today] the social process itself is different. There aren't rallies in the plaza all the time. Life has changed so that the process itself is more profound, more complex, and less evident.

\section{Beltrán commented on the same phenomenon:}

the current poster has to deal with a more complex body of ideas which are less able to be converted into visual form. For example, in the early days, an idea for a poster might be "you must study to help the revolution." This is easier to represent in visual form than the concept of the importance of economic efficiency. 
Basically, this new trend in photography involves a more personalized, more insightful, and, in a certain sense, more respectful reflection of society - that is, the consolidation of the Revolution has been visually acknowledged. Photographic aesthetics are evolving; less weight is given to eliciting emotions and impressing the viewer, and more to spontaneity, to a certain traditional type of beauty, and to individual expression (only in the last few years have Cuban photographers started to sign their work and to discuss the possibilities of copyright). This can be seen in the photograph by Mayra Martínez of four young girls standing in a pool of rushing water (Figure 8) or in those by Corrales of young people in a summer work camp (Figures 9-13). Martínez's composition probably would not have received any attention immediately after the Revolution, and Corrales's subject would have been treated in a heroic, exemplary manner. Today, however, he concentrates instead on the comeliness and gracefulness of the human form, the overall composition, and the uninhibited, silly reactions of some of the teenagers in front of the camera.

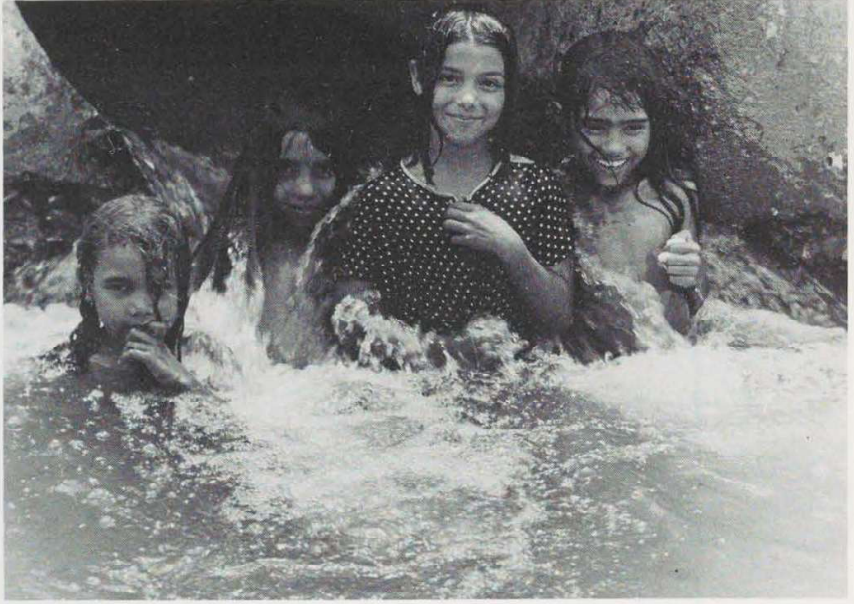

Figure 8 Mayra Martínez.

Untitled, n.d.

Figure 7 Grandal. Untitled, n.d. (Reproduced from XX Aniversario, p. 80.)

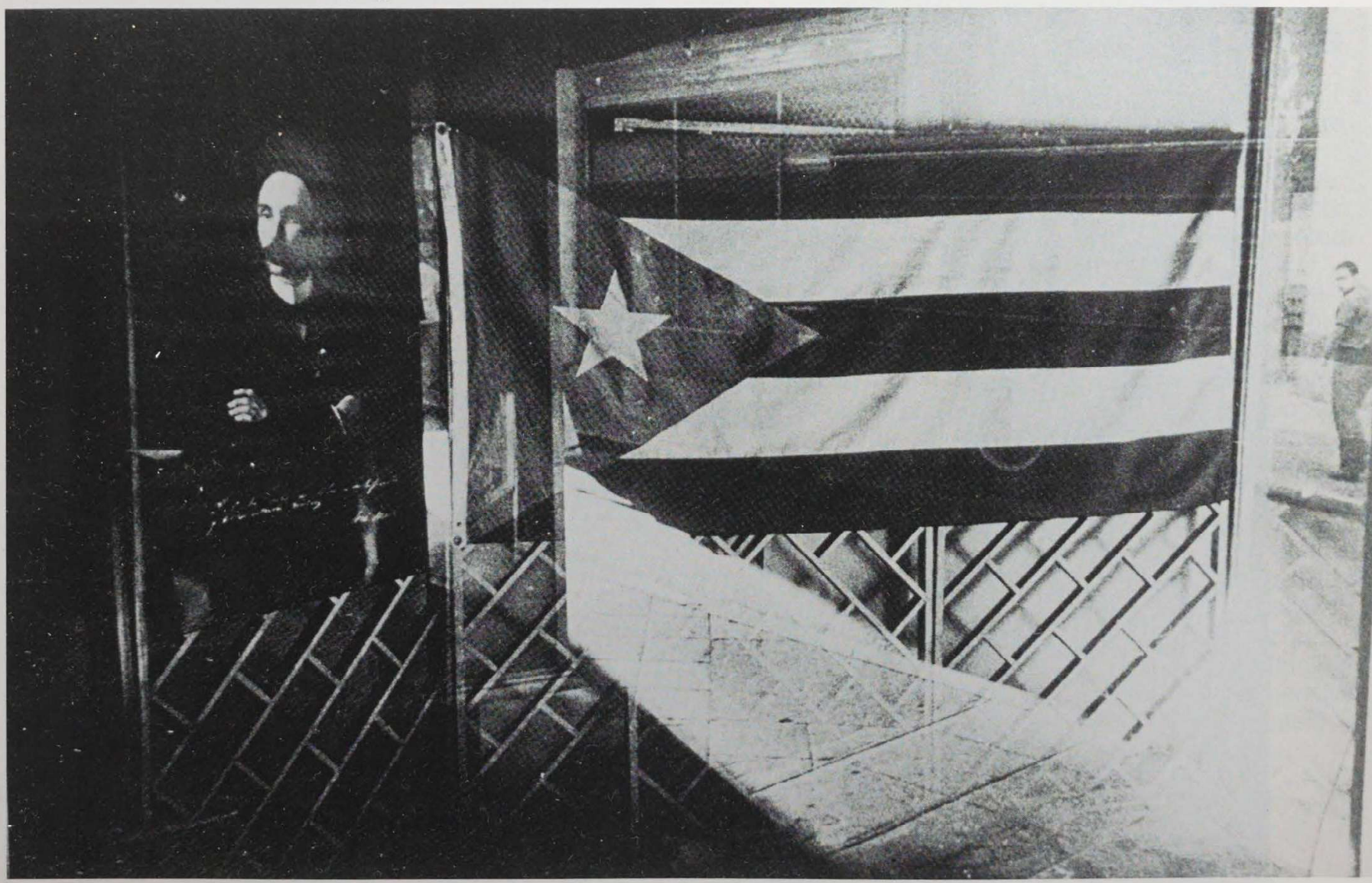




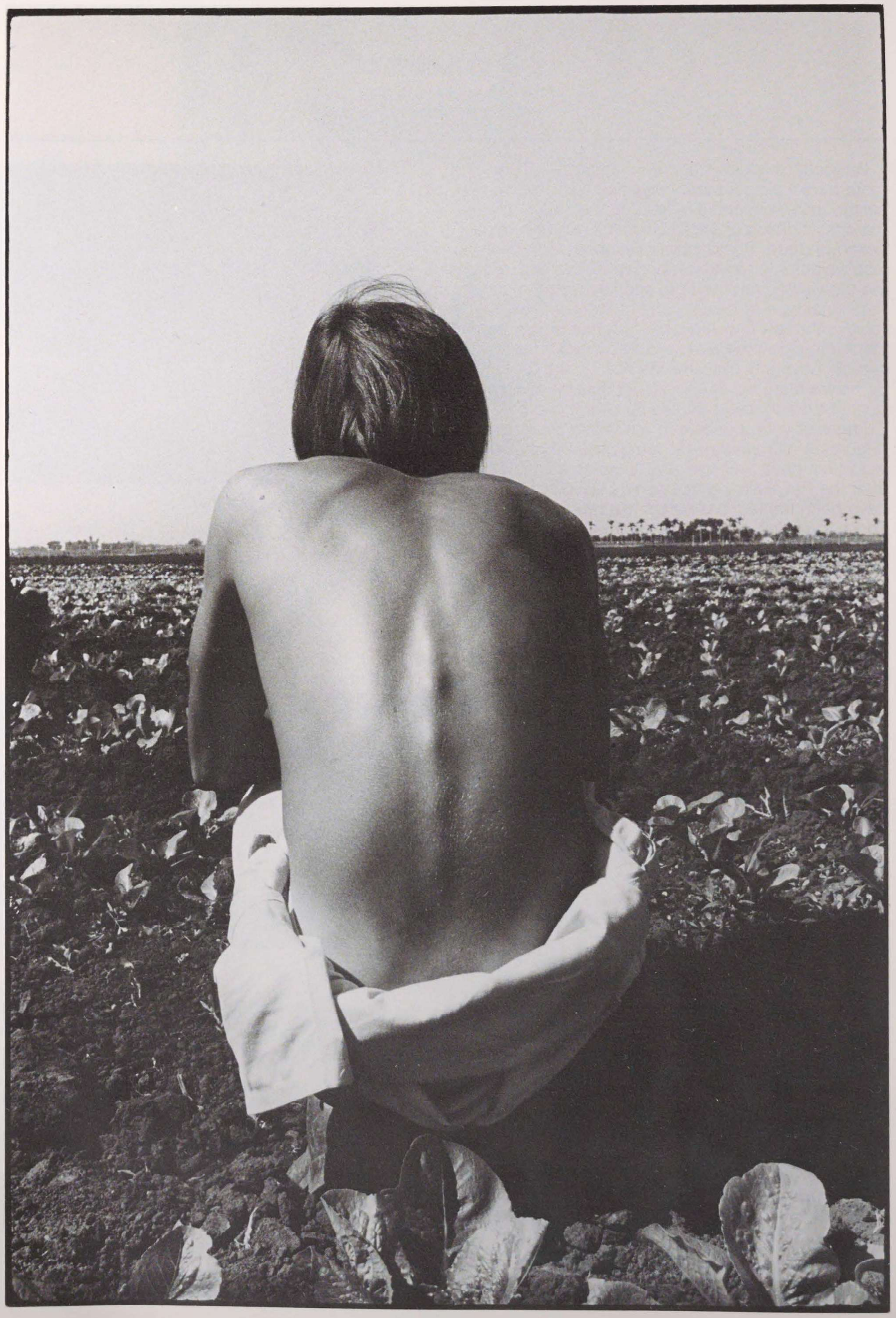




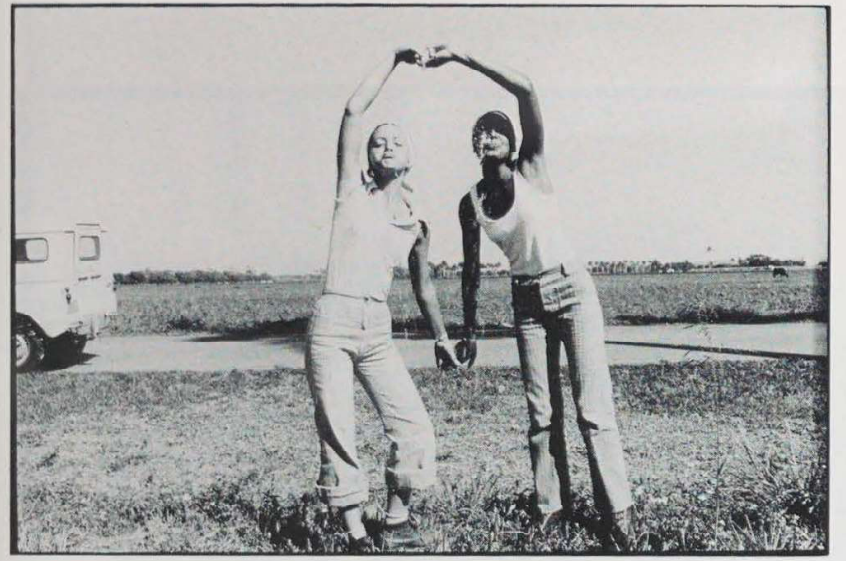

Figure 10 Corrales. Untitled. From the series "Campo de verano," 1980.

\section{Publication and Exhibition}

Although the general outlook has evolved, there is a decided stylistic homogeneity in Cuban photography since 1959. I have never seen a modern Cuban photograph with a long, soft, tonal range; obviously, highcontrast images are visually more striking than subtle ones. Part of this penchant for high-contrast work is due to the fact that Cuban photography has been primarily intended for publication rather than for exhibition; delicate textures, suave nuances, and a gentle tonal range do not reproduce well on the primitive printing presses and cheap papers found in Cuba. In addition, the Photographic Subsection of UNEAC was not founded until late 1977, and one of its responsibilities has been to disseminate photography and arrange photographic exhibitions. Previously, professional photographers had seen very few exhibition prints, and their aesthetic was probably based largely on what they had seen in Cuban publications. It is also probable that, ideologically, they might consider virtuoso printing self-indulgent and wasteful.

Moreover, obtaining materials is a serious problem, since the arrival of film and enlarging paper from East Germany is unpredictable and haphazard. The photographer Alberto Figueroa explained that once, in order to make an exhibition of fifty photographs, he was allotted a box of fifty sheets of paper-and he added: "What you get out of this are about forty-five photographs that are poorly printed." ${ }^{6}$ Obviously, photographers in less industrialized countries are at a disadvantage: the prices of photographic goods are high and the distribution is shoddy. However, Corrales felt that this made him technologically less dependent and more experienced with improvisation than some of his foreign colleagues. He commented that sometimes he gets nine negatives off a roll of thirty-six that he feels are "good" and that he uses. He suggested that the minuscule percentage of interesting negatives obtained by many professional photographers in more developed countries called into question their abilities. The lack of photographic goods in Cuba causes photographers to be less experimental and less wasteful and, at the same time, more respectful of what they have and more motivated to obtain images which are meaningful to them.

I also asked Mayito why so many Cuban photographers use wide-angle lenses. He said that there were two reasons for this. First, they are less expensive and, consequently, more readily available. Second, the photographers like the wide-angle vision, finding it less limiting and less exclusive, more comprehensive and democratic, as well as including more context "in a country where it is always important."
Figure 9 Corrales. Untitled. From the series "Campo de verano," 1980. 


\section{Subject Matter}

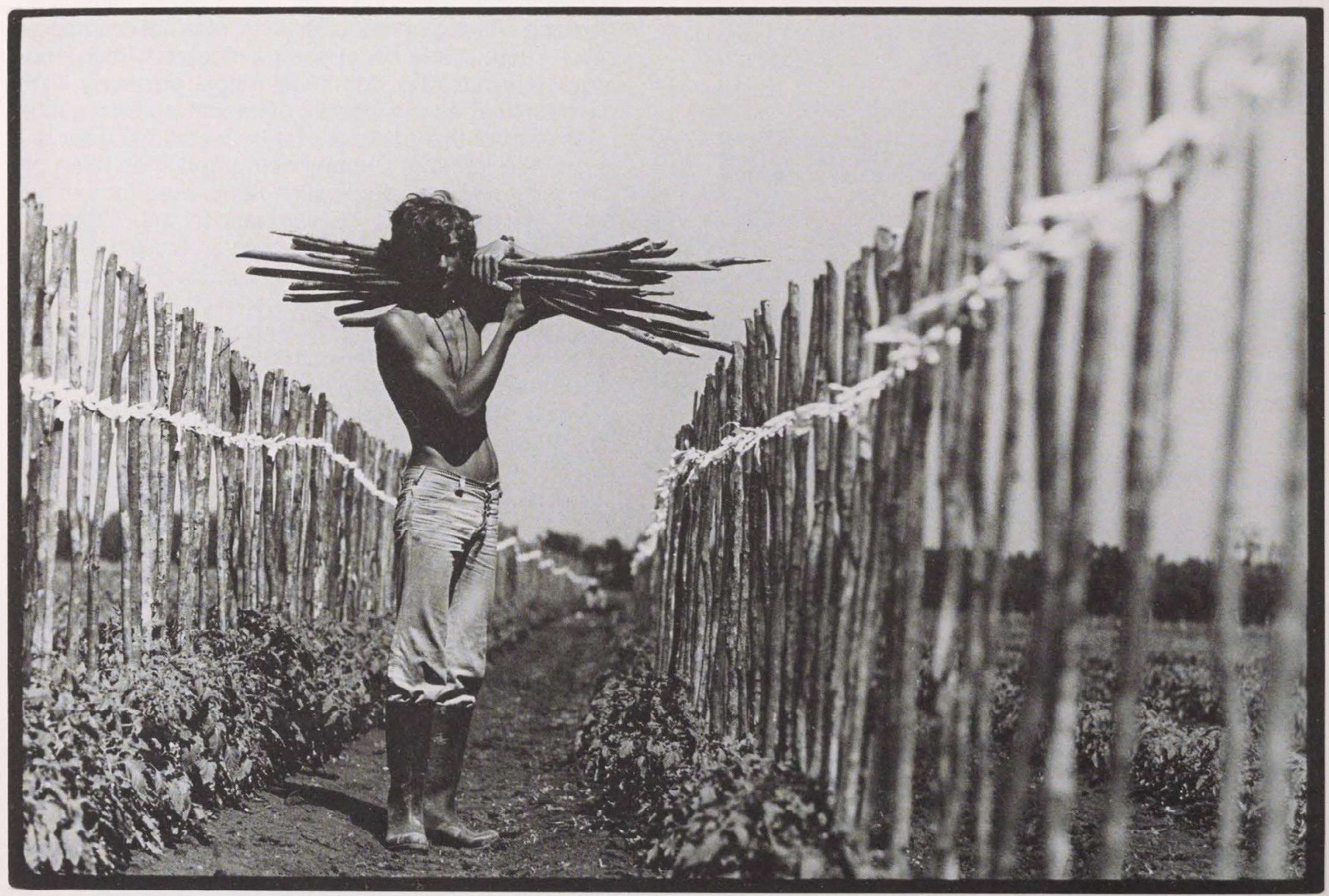

Figure 11 Corrales.

Untitled. From the series "Campo de verano," 1980.

Figure 12 Corrales. Untitled. From the series "Campo de verano," 1980. 


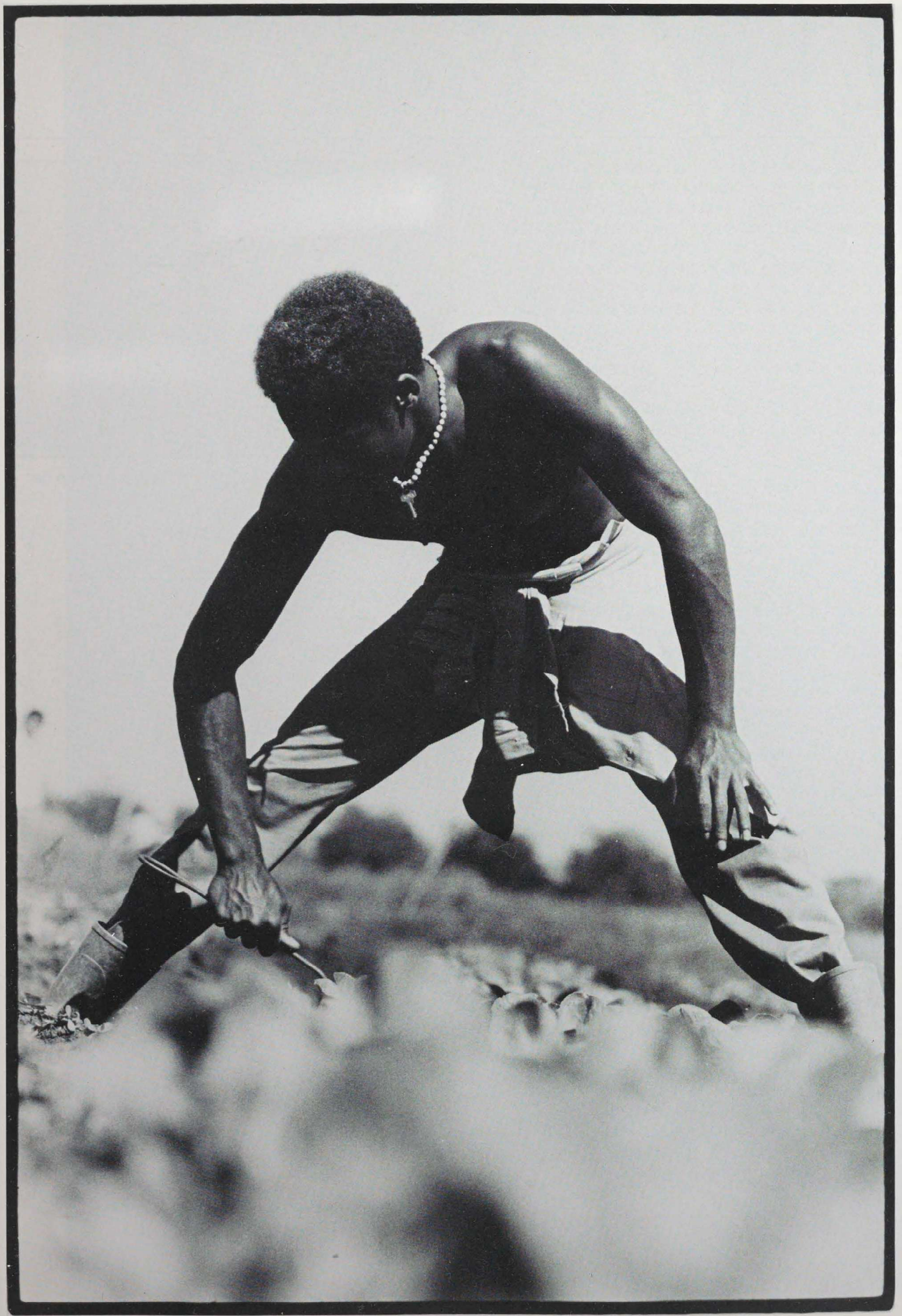


Since the Revolution in 1959, Cuban photography has almost exclusively used people for subject matter, as opposed to photography in the United States during the same period, in which people have become a less and less popular theme (Figures 11-20). I have never seen a post-Revolutionary photograph of a nude; Mayito called it an "old theme," like the gravures of lovely ladies that once decorated cigar boxes. Landscapes, still lifes, and abstract compositions, which he described as "decorative," are rare. Mayito commented that "when things that are so important are taking place, it doesn't make sense to be shooting pictures of little pieces of wall."

It is also worth noting that the people who are the subjects of these Cuban photographs seem incredibly normal, representative, and ever-present. Often they seem delighted, not bored or offended, at having their picture taken, almost as if the fact that they were being recorded made a vital difference, as if this were some sort of affirmation of their individual importance. Obviously, they have not been overworked as the subjects of family snapshot sessions-especially since there is not a camera in every household. (Mayito commented that amateur cameras could be purchased occasionally but that the percentage of people owning cameras was considerably lower than that in Mexico.) The subjects are rarely singled out because of their unusual dress, behavior, status, attitudes, or deformities. The fact that they are seldom identified in the titles does not seem to leave the viewer with unanswered questions, as it might in other cases. Even if the photograph is created as a portrait, the subject is usually not isolated against a plain background, but appears instead against a group of people, a sugar cane field, the side of a postered building, or a corner of a work place. In relation to this, Mayito quoted Engels: "The fundamental forms of every being are space and time, and a being conceived outside of time is as absurd as one conceived outside of space."

Mayito elaborated on the common thematic interest of Cuban photographers, despite the differences in their ages and education, by emphasizing that it was a result not of "directed cultural politics" but of their involvement in the problems of the moment. None of the photographers, he claimed, was alienated from contemporary reality. He said that many of them were members of the militia (including himself) and others did voluntary work together: "They were all concerned with what Reagan said in the morning to decide what they would do in the afternoon."

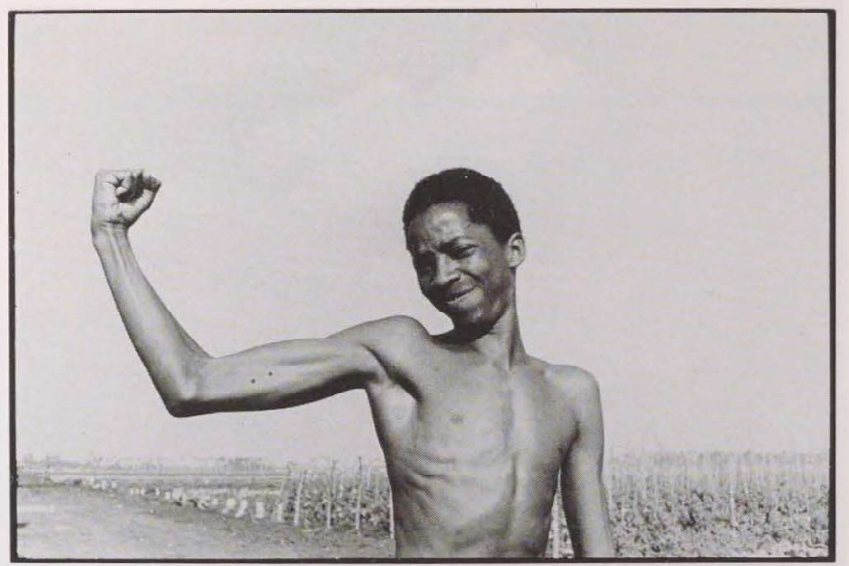

Figure 13 Corrales. Untitled. From the series "Campo de verano," 1980.

Figure 14 Corrales. Untitled, 1957-1959. 


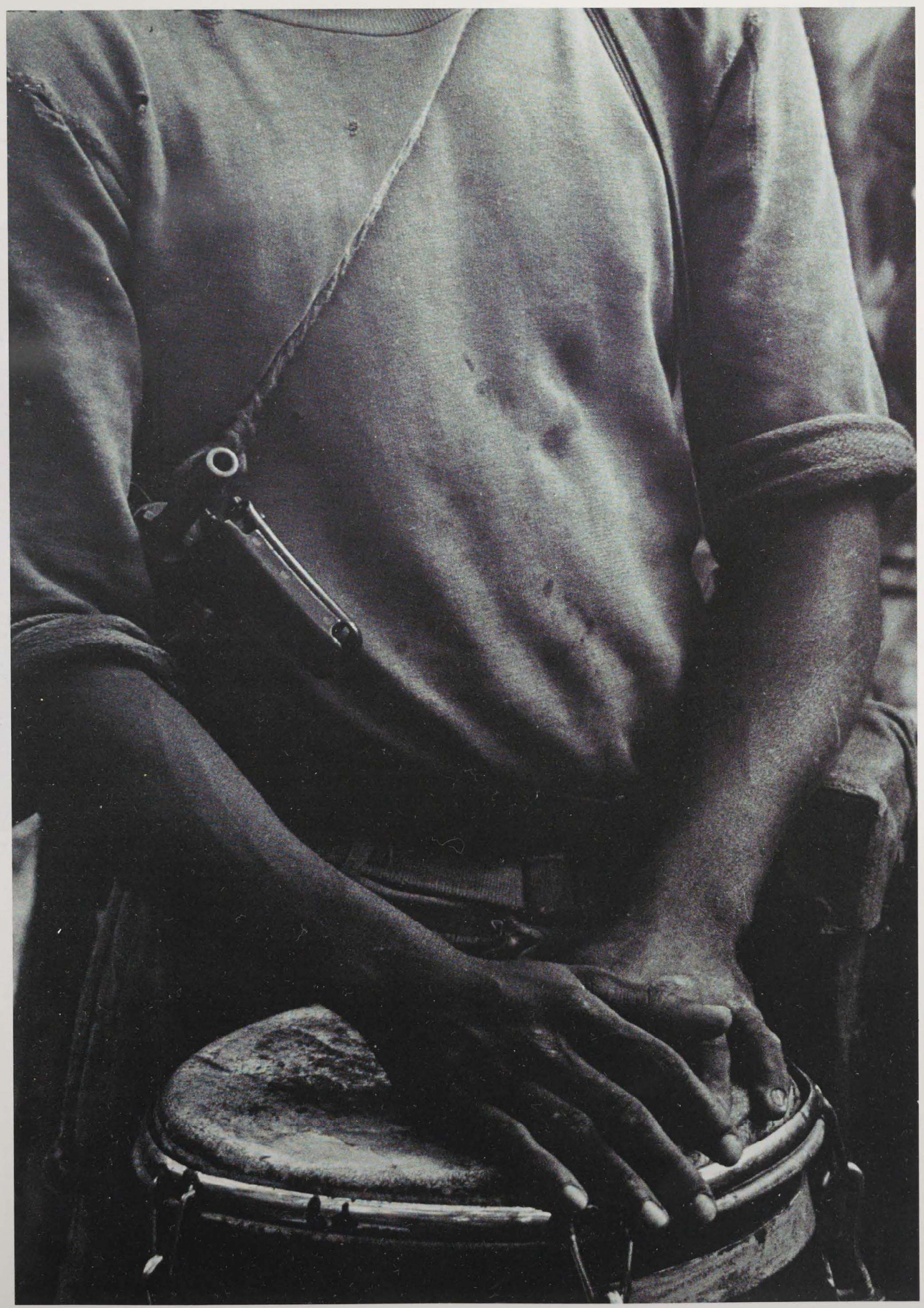




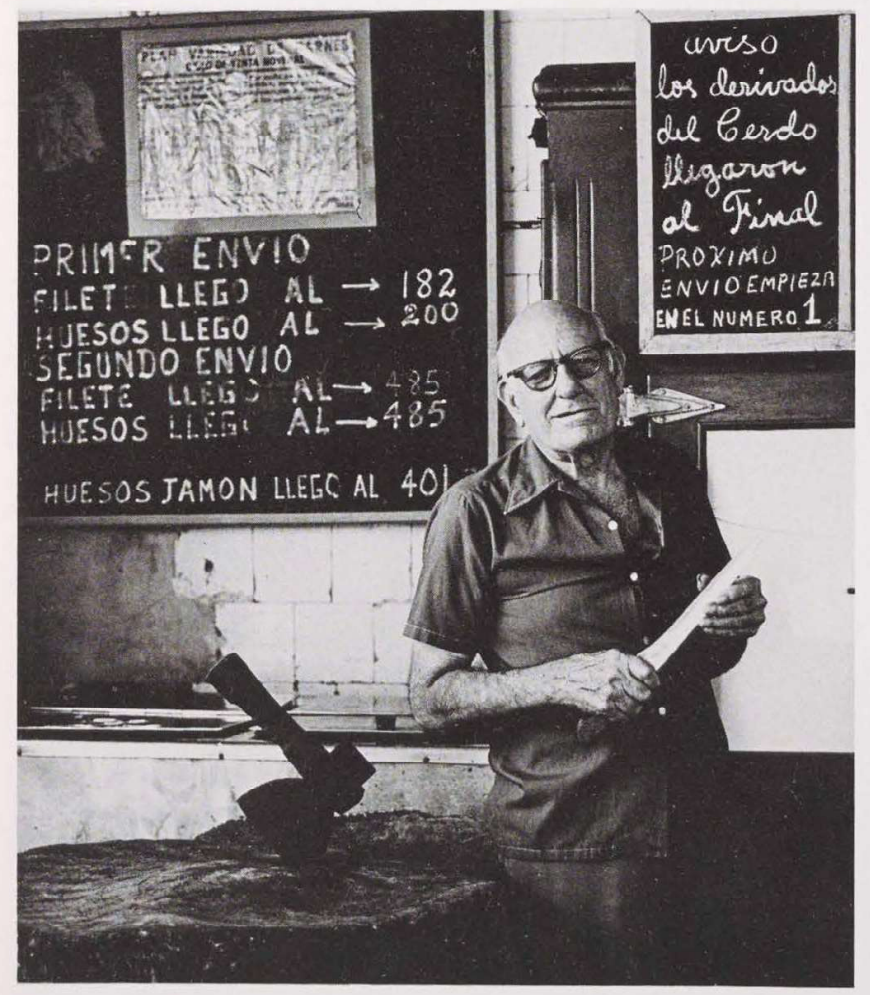

Figure 15 Tito Alvarez. Untitled. From the series "La gente de mi barrio," ca. 1980.

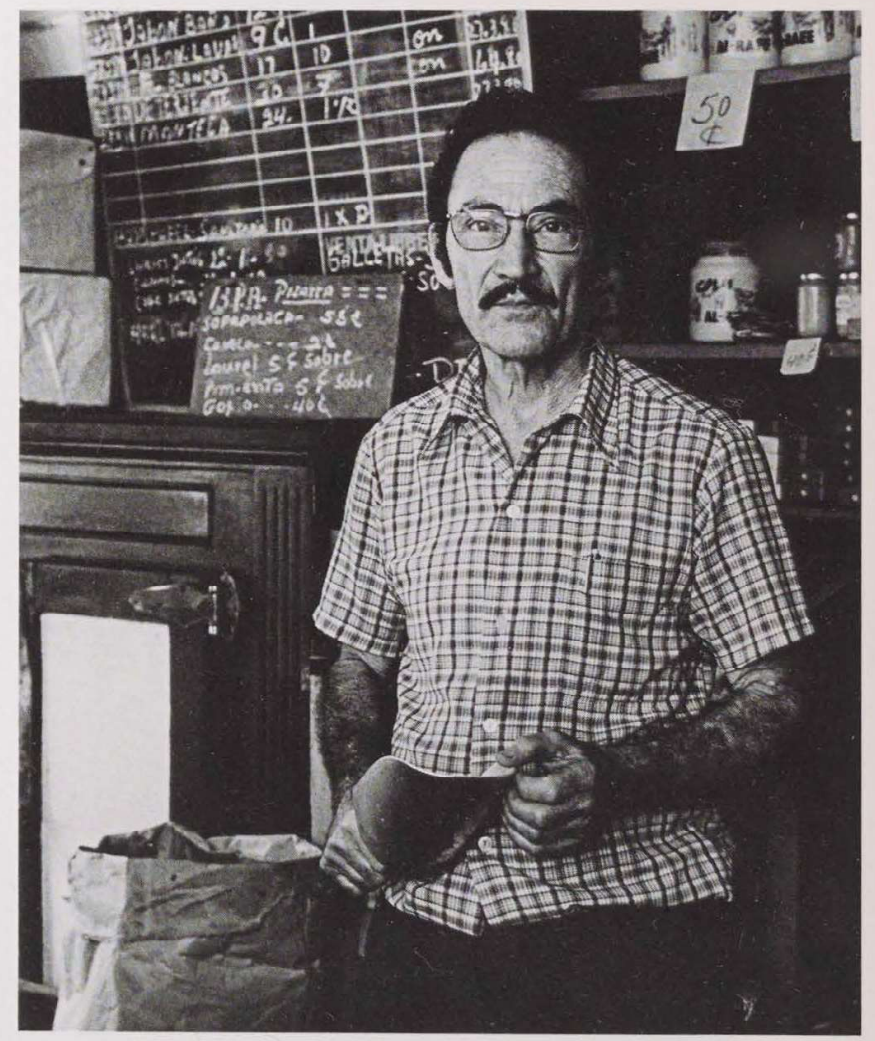

Figure 16 Tito Alvarez. Untitled.

From the series "La gente de mi barrio," ca. 1980. 


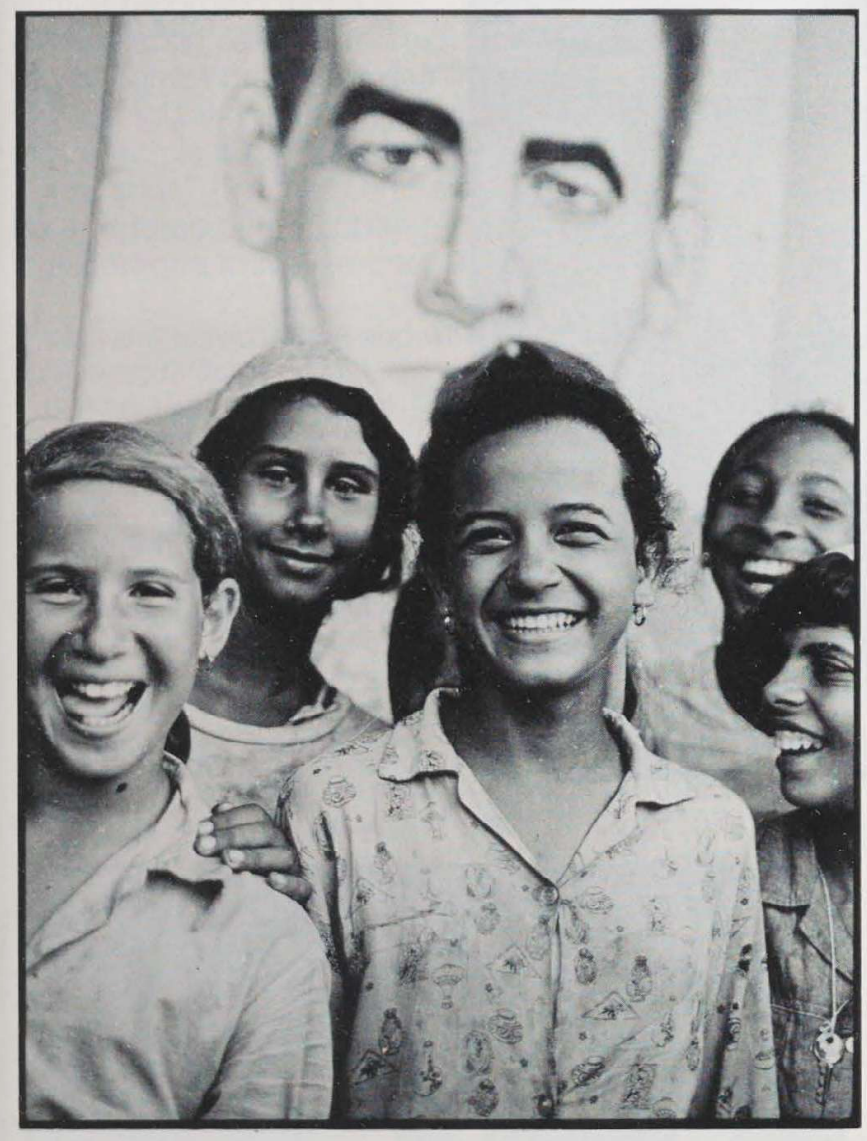

Figure 17 Mayra Martínez. Untitled, n.d.

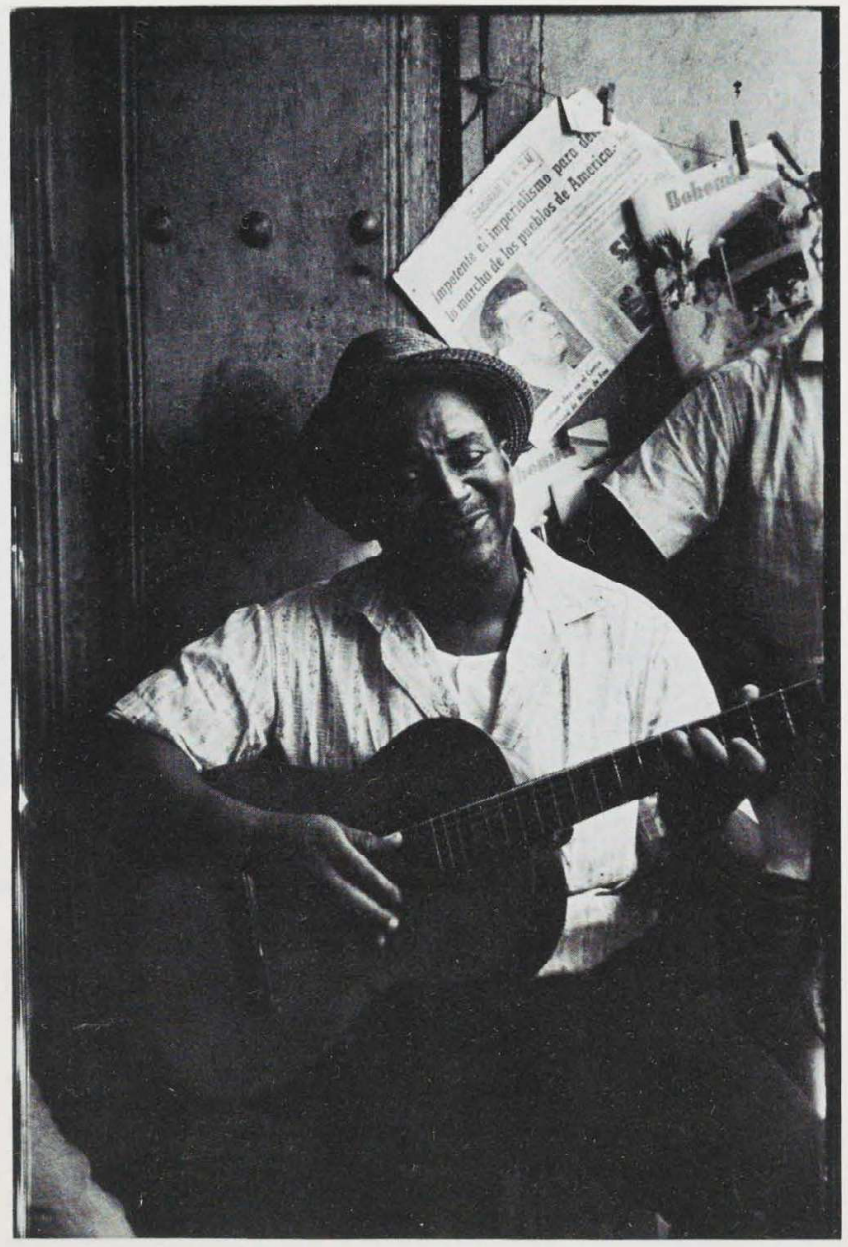

Figure 18 Mayito. Untitled, n.d. 


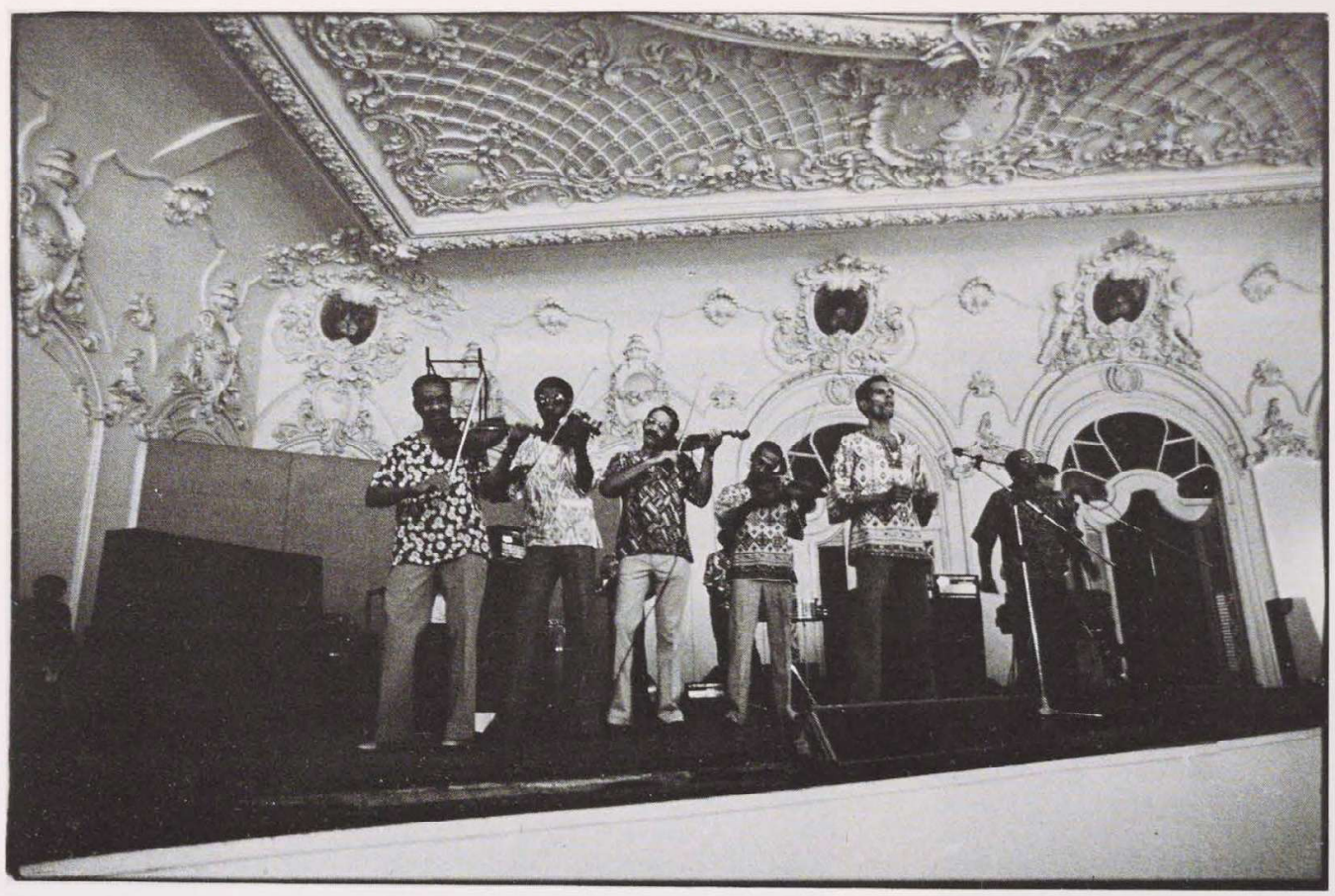

Figure 19 Marucha.

Untitled, 1979.

Figure 20 Marucha. Untitled, 1979.

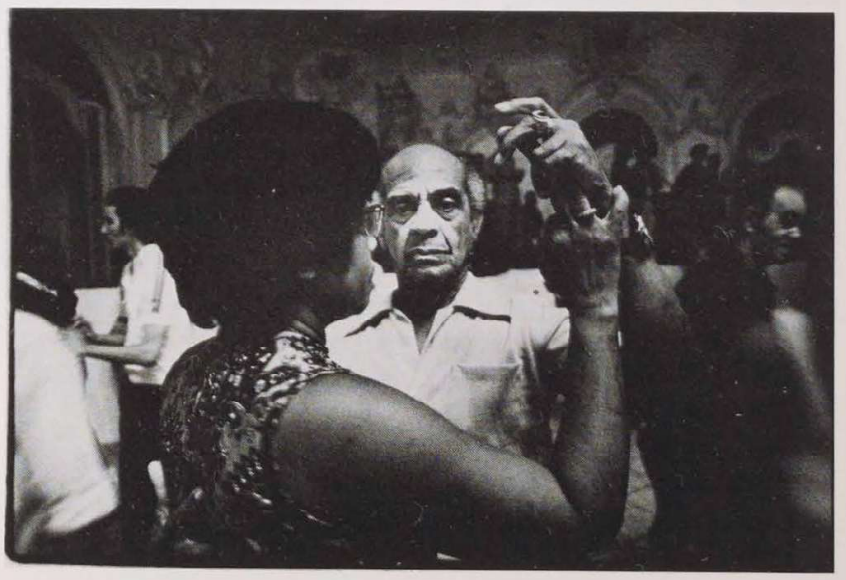




\section{Attitudes toward Photography}

Since neither of us believes that the camera is an objective recording tool, I asked him how he felt about manipulating reality. He said: "Everyone has a point of view and I project myself from my point of view. that is ethical; ... It is not the same as lying or inventing, which is illicit." Mayito mentioned the project "Hermanos" [Brothers and sisters] (Figure 21) which he and three other Cuban photographers undertook in Nicaragua in November 1980:

We went to Nicaragua and we got the image of Nicaragua that we wanted to give, that emerged from our principles and our criteria-and we believe in principles that are revolutionary. That is not manipulation or a lie. That is licit. If a photographer from the United Press goes to Nicaragua, he will make another reality. So it's logical that we'll make ours. No? And, in a certain sense, we also did it to show the other side - to show what we believe is truer than the alternative. ... Although there are no absolute truths, there are some that are a little larger than others.

Finally, I asked the Cuban photographers with whom I was talking why they made photographs Mayito answered: "Why do I make photographs? Because I don't write poetry." Corrales quickly replied: "Because I don't write poetry either. " Marucha said: "Because it's a way of expressing so many things I have to express."

Compared to the contemporary art/photo scene in the United States, Cuban photography from UNEAC might be considered classic, ultraconservative, wholesome, and thematically and technically unoriginal. These photographers are not, however, living in a consumer-oriented society; artistic originality, intuition, and individualism are not valued to the extremes that have motivated photographers in the United States, as they have in radical cases, to concentrate on masturbation, stretch marks, child porn, or unauthorized portraits in a morgue of an autopsied corpse dressed in a lace brassiere. Violation of privacy and exploitation of minors and others in the name of Art do not arise in contemporary Cuban photography from UNEAC.

Rather than comparing artistic freedom in the United States and Cuba, it would seem more relevant to consider what values the market will support-in Cuba, the market being largely UNEAC, and in the United States, dealers, museum directors, book publishers, and individual collectors. Some themes which have been successful in exhibitions in the United States, such as apathy, conceptualism, and introspection, do not appear to have emerged as acceptable, viable, or even interesting subjects to Cuban photographers associated with UNEAC. What I have seen of their work and what I have understood from talking with them would indicate that these particular

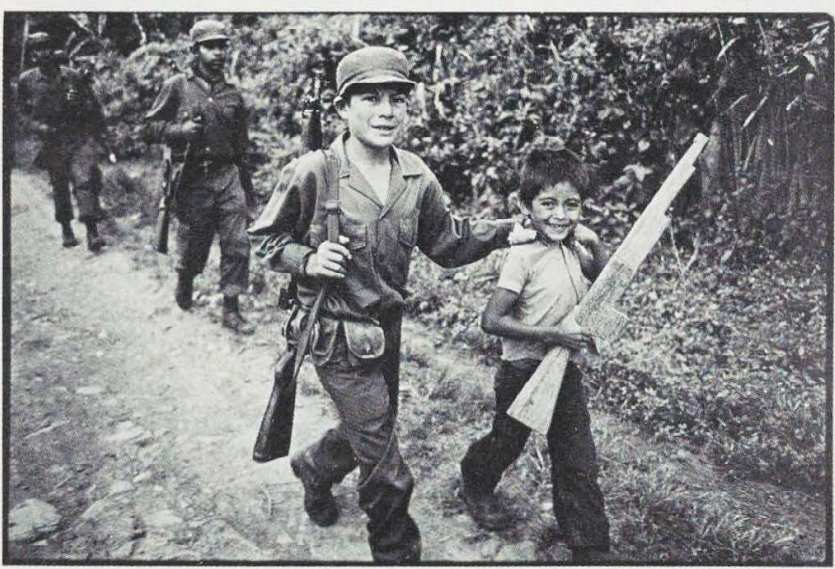

Figure 21 Mayito. Untitled. From the series "Hermanos," 1980. (Reproduced from Fotografie Lateinamerika von 1860 bis Heute, Zurich, 1981, p. 300.)

men and women, who are part of an elite, care deeply about their society and that for them art is not a superstructural entity or a luxury but is capable of making a difference_-perhaps even, in some ways, of "making man happier, better.

Clearly, membership in UNEAC and the opportunity to exhibit abroad are limited by what appeals to others, a process of selection that has profound implications about freedom of expression. Whether an "old boy network" exists is extremely difficult to evaluate. I also do not know the consequences or possibilities of a photographer not associated with UNEAC submitting work, as an individual, to an international photographic competition. I can imagine, however, how depressing it would be for a photographer who believes in the merits of his or her own work to be refused membership in UNFAC, since it is the only available group of its kind-if for nothing more than obtaining materials and facilities.

It must be kept in mind that the availability of photographic equipment and supplies is and will be limited in Cuba for economic reasons and that, instead of distributing these goods to photographers according to some sort of lottery or placing them on the open market so that only the wealthiest would be able to photograph, the government, through UNEAC, prefers to allot them to those photographers who are projecting the image of Cuba which they wish to see projected. These values are not unlike those employed by the United States Information Service for selecting photographs to represent the United States abroad. However, in Cuba, as the economic situation has gradually become less pressing over the last twenty years, photography, especially thematically 
and compositionally, has become less graphic, exemplary, and idealistic, and more personal and spontaneous. What is persistent in the photographic work since the Revolution is the pride that these photographers convey about Cuba's positive accomplishments, sometimes in the face of impressive odds, and their continued awareness of and involvement in the development of their country.

\section{Notes}

1 Unless otherwise noted, all translations are mine, and any statement by Raúl Corral Varela, Marío García Joya, or María Eugenia Haya comes from my interview (in Spanish) with them in Mexico City on May 2, 1981, or from conversations which we had individually.

2 All statements by Félix Beltrán quoted in this article come from Eve Cockroft, "Art in Cuba Today: An Interview with Félix Beltrán," Art in America 68 (January 1980), pp. 9-11.

3 "¿Cuales son los derechos de los escritores y de los artistas revolucionarios o no revolucionarios? Dentro de la revolución: todo; contra la revolución ningun derecho [sic]." Fidel Castro, "Palabras a los intelectuales," cited in Adolfo Sanchez Vazquez, Estética y marxismo (Mexico City: Ediciones Era, 1970), vol. 2, p. 406.

4 "Es libre la creación artística siempre que su contenido no sea contrario a la Revolución. Las formas de espresión en el arte son libres. "Educación y Cultura (Capítulo IV de la Constitución de la República de Cuba, procalamada el 24 de febrero de 1976)" in Politica cultural de la revolución cubana: documentos (Havana: Editorial de Ciencias Sociales, 1977), art. 38d, p. 138

5 "Fue muy usual que durante los momentos más delicados y decisivos, en apoyo a los patrióticos y dramáticos llamados de la Revolución, se utilizara la fotografía como lenguaje para sensibilizar y movilizar a las masas a través de la prensa o impresa directamente en carteles y vallas, con textos como los siguientes: 'Estos cubanos necesitan tu ayuda' ... 'iA las armas!', 'A la Plaza', 'iComandante en Jefe, ordene!' y otros." María Eugenia Haya, "Sobre la fotografía cubana," Revolución y cultura (May 1980), p. 54.

6 ". . . por eso una exposición así sale con cuarenta y pico de fotos más o menos, mal impresas. ..." "Frente al lente," Revolución y cultura (May 1980), p. 31.

7 "Las formas fundamentales de todo ser son el espacio e el tiempo, y un ser concebido fuera del tiempo es tan absurdo como lo sería un ser concebido fuera del espacio." F. Engels, Anti-Duhring, cited in Marío García Joya, "Relación entre realidad y estilos de la fotografía en América Latina," Memorias del primer coloquio latinoamericano de fotografía (Mexico City: Consejo Mexicano de Fotografía, 1978), p. 15.

\section{References}

- Cagan, Steve

1980 Documentary Photography in Cuba. Radical America 14, September-October.

- Cardenal, Ernesto

1974 In Cuba. Donald Walsh, tr. New York: New Directions.

- Hart, Armando

1977 ¡Ha triunfado la justicia! Adelante el arte. Revolucíon y cultura, November.

- Haya María Eugenia

1979 Apuntes para una historia de la fotografía en Cuba. 1959/ 1979: XX Aniversario Casa de las Américas. N.p. [Havana]: INBA, May-June.

- P[orter], A[llan]

1980 Grandal. Camera, January.

- Thomas, Hugh

1977 The Cuban Revolution. New York: Harper and Row. 